\title{
Purchase Loyalty which is Influenced by Brand Awareness and Perceived Quality
}

\author{
Irsal Fauzi ${ }^{1}$, Meida Rachmawati ${ }^{2}$, Mona Inayah Pratiwi ${ }^{3}$, Abdul Aziz ${ }^{4}$, Ahmad Ali ${ }^{5}$, \\ \{rrsalfauzi@unw.ac.id¹,meida_r@unw.ac.id ${ }^{2}$, monainayahpratiwi@unw.ac.id ${ }^{3}$, abdulaziz@unw.ac.id ${ }^{4}$, \\ ali.ahmad.coffie@gmail.com ${ }^{5}$ \} \\ Universitas Ngudi Waluyo, Ungaran
}

\begin{abstract}
One of the marketing strategies that can be applied in winning the market competition is a brand development strategy. If a brand is introduced or communicated through advertisements in various media, this will lead to brand awareness as the first step so that a brand can be better known to the public and become an alternative product of choice. Companies that are active in instilling certain brand associations in the minds of consumers can form a different image from other brands. The formulation of the problem in this study is: What is the effect of Brand Awereness What effect does (brand awareness) have on consumer buy loyalty? What impact does Perceived Quality have on customer buy loyalty? Multiple linear regression analysis was employed in this investigation. The census sampling approach was utilized to choose the sample for this investigation. The findings revealed that: Purchase loyalty is influenced by brand awareness in a positive and significant way. Purchase loyalty is influenced by perceived quality in a positive and significant way.
\end{abstract}

Keywords: Brand Awareness; Perceived Quality; Purchase Loyalty

\section{Introduction}

One of the marketing methods that can be used in a variety of situations winning the market competition is a brand development strategy. Brands that are introduced and communicated through advertising will create brand awareness as a first step so that a brand can be better known to the public and become an alternative product of choice. Companies that are able to strengthen certain brand associations will form a different image with other product brands. Therefore, companies that always try to make target consumers satisfied with the quality of their products, then these consumers will have high brand loyalty, then these consumers will repurchase the product in the future. Brands can be utilized to gain a competitive edge by attracting potential buyers. It will be easier for businesses to earn income and secure a long-term future with the power of a large brand [1]. Almost all companies invest tens of billions in brand development. Nevertheless, the risk of brand failure still occurs which ends in the death of the brand [2].

Strong brand equity must have elements Brand awareness, brand connotations, perceived quality, and high brand loyalty are all important factors to consider. Customer loyalty is important. is not easy to get, but must go through various ways that can make an impact for 
customers to have product loyalty. The first step in forming loyalty starts with customer awareness will product. At this early stage, consumers begin to form the thought perceptions needed to positioning in the minds of consumers that the product or service they choose is superior to competitors [3]. The results showed that the identity of brand has an influence on brand image. Thus, the better the brand identity formed by the company, the better brand image in the eyes of consumers. As well as On the other hand, if the brand identity that is formed by a bad company, then the brand image in the eyes of consumers will be bad [4]. The results showed that brand awareness has an influence on consumer loyalty. Important reasons for managing and developing brand equity are Brand means more than just a product. The product only describes its dimension attributes which are will be interchangeable and Other companies can readily mimic the brand, but the brand can explain emotions and special ties with customers and is intangible, making it difficult for competitors to imitate. The higher a product's brand equity is, the more consumers will be motivated to choose it [5].

\section{Loyalty and the Buying Cycle}

Every time a customer buys, he or she moves through the buying cycle. The steps that the customer goes through are:

a) Awareness

At this stage the customer begins to form the "share of mind" needed to promote the product as a product that is superior to competitors. The emergence of awareness can be through conventional advertisements (radio, TV, newspapers), advertisements on websites, word of mouth communication and others.

b) Early Purchase

The first A trial purchase allows a corporation to leave a positive or negative impression on clients.

c) Post-purchase evaluation

After a purchase is made, the customer consciously or unconsciously evaluates the transaction. If you feel satisfied or not so disappointed with the product you bought, then the decision to repurchase is possible.

d) Repurchase decision

Repurchase commitment is a vital attitude for loyalty.. This occurs when the customer already has a strong emotional bond with the product.

e) Repurchase

Truly loyal customers reject competitors and repurchase the same product whenever needed.

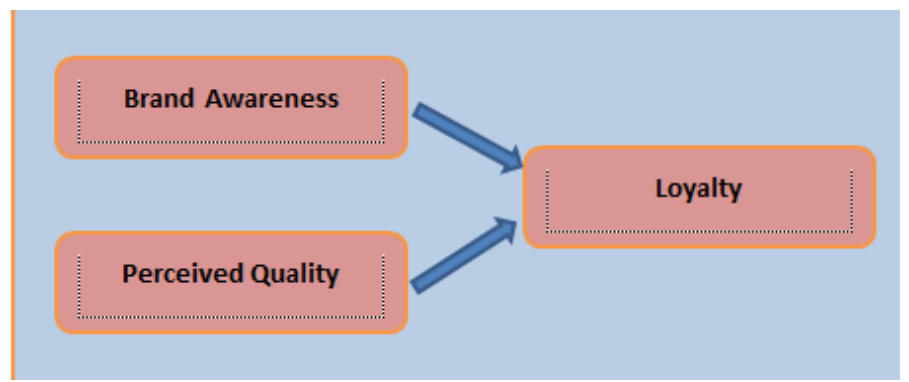

Fig. 1. Framework of Brand Awareness and Perceived quality to Loyalty 
Loyalty and the purchasing cycle are related to brand awareness and perceived quality. There can be no loyalty without consumers knowing the product brand that has been embedded in their minds, and certain brands are always associated with product quality perceptions that are firmly entrenched in consumers' minds.

\section{Results and Discussion}

Table 1. T Test. Regression test on loyalty as a dependen variable

\begin{tabular}{cccc}
\hline Model & Standardized Coefficients & t & Sig \\
\hline Brand Awareness & .052 & $\mathbf{9 . 3 5 2}$ & .001 \\
Perceived Quality & .605 & $\mathbf{7 . 0 5 6}$ & .000 \\
\hline
\end{tabular}

The results of testing the effect of brand awareness on purchase loyalty obtained a value of $\mathrm{t}=9.352>\mathrm{t}$ table of 1.6939 with a significance $(\mathrm{p}<0.05)$. With a significance less than 0.05 and a positive direction of the coefficient, it is obtained that Hypothesis 1 is accepted. This signifies that brand awareness influences buyer loyalty in a good and significant way.

The outcomes of testing the effect of perceived quality on performance obtained a value of $\mathrm{t}=7.056>\mathrm{t}$ table of 1.6939 with a significance $(\mathrm{p}<0.05)$. With a significance less than 0.05 and a positive direction of the coefficient, it is obtained that Hypothesis 2 is a valid answer. This suggests that perceived quality influences purchase decisions in a favorable and meaningful way loyalty.

Measurement Analyzing the basic characteristics of brand equity, such as brand awareness (brand awareness), brand association (brand association), perceived quality (perceived quality), and brand loyalty (brand loyalty), can be done (brand loyalty). To get to know a product other than the brand, and to give or even To improve the function of the brand, it is necessary to instill brand awareness or brand presence in the memory of consumers, with the aim of distinguishing one product from another or competitor products. Customer loyalty can also be explained as an emotional commitment from customers towards the brand, and this is quite difficult explained because it relates to feelings the customer himself who believes in the brand and emotionally attached to a product or service.

Measurement brand equity can be done by analyzing the basic brand awareness, brand association, perceived quality, and brand loyalty are all aspects of brand equity. To get to know a product other than the brand, and to give or even To improve the function of the brand, it is necessary to instill brand awareness or brand presence in the memory of consumers, with the aim of distinguishing one product from another or competitor products. Customer loyalty can also be explained as an emotional commitment from customers towards the brand, and this is quite difficult explained because it relates to feelings the customer himself who believes in the brand and emotionally attached to a product or service.

Perception of the product can be divided into Perception on the quality (perceived quality) and the value acquired perception (perceived value). Consumer perception of overall quality is referred to as perceived quality or service of services with the intention of expected by consumers [6]. Perceived quality is important for considered by the company because this perceived quality will shape In the viewpoint of customers, the perceived quality of a product. The value of a product or service can be determined by one's perception of its overall quality and have a direct effect on the consumer purchasing decisions on brands [7]. The consumer's perception of a product that is judged to be of high quality plays an important role in the 
occurrence of repeated purchases which is a feature of the formation of a high loyalty attitude from consumers. Thus, perceived quality has a direct effect on consumer loyalty.

\section{References}

[1] D. Aaker, Aaker on Branding 20 Prinsip Esensial Mengelola dan Mengembangkan Brand. Jakarta: PT Gramedia Pustaka Utama., 2015.

[2] P. Temporal, Perilaku Organisasi Konsep, Kontroversi, Aplikasi. Jakarta: PT. Prenhalindo.

[3] Griffin, Customer Loyalty. Jakarta: Erlangga.

[4] C. F. Tingkir, "Pengaruh Identitas Merek Terhadap Loyalitas Merek Melalui Citra Merek Dan Kepercayaan Merek Toyota," J. Manaj. Pemasar., vol. 8, no. 2, pp. 62-69, 2014, doi: 10.9744/pemasaran.8.2.62-69.

[5] F. H. H. Quantrianto, P. T. P. Hutomo, and E. S. Pujiarti, "Pengaruh Brand Awareness, Brand Association dan Perceived Quality terhadap Customer Relationship Management Kecap Manis Merek ABC," J. Ilm. Din. Ekon. dan Bisnis, vol. 1, no. 1, pp. 89-101, 2013.

[6] T. Durianto, D., Sugiarto, \& Sitinjak, Strategi Menaklukkan Pasar Melalui Riset Ekuitas dan Perilaku Merek. Jakarta: PT. Gramedia Pustaka Utama.

[7] M. D. Foster, B., \& Johansyah, "EWOW'S Strength on Brand Image and Brand Trust and its' Impact on Interest to Buy IPhone Smartphone Products. International Journal of Innovation, Creativity and Change (IJICC)," vol. 9(12), pp. 79- 93, 2019. 